\title{
Adaptation of the Four Forms of Employee Silence Scale in a Polish sample
}

\author{
Krystyna Adamska $a^{A, B, C, D, E, F}$, Pawet furek ${ }^{A, B, C, D, E}$ \\ Institute of Psychology, University of Gdansk, Gdansk, Poland
}

\section{BACKGROUND}

Silence is understood as a decision not to speak up in situations of observed irregularities both in productivity and ethics. The study examined the validity of the Four Forms of Employee Silence Scale (FFESS) in the Polish population. The scale is a four-factor measure designed to capture differently motivated tendencies to be silent in organizations. The scale distinguishes acquiescent, quiescent, prosocial and opportunistic silence. Employee silence has been linked to many important individual outcomes: failure to react to ethical transgressions, stress and depression, and lower creativity and productivity.

\section{PARTICIPANTS AND PROCEDURE}

A total of 1044 employees of various organizations working for at least six months at a given position provided the responses for the validation study.

\section{RESULTS}

The results confirmed the superiority of the four-factor model shown by adequate fit indexes: The FFESS has ad- equate internal consistency at both the scale and item levels. The criterion-related validity of the scale was established by correlating four forms of silence with measures of emotional attitude toward organization, procedural justice, relational contract and turnover intention.

\section{CONCLUSIONS}

The four forms of employee silence are empirically distinct concepts in the Polish sample. The scale may be used as the measurement of individual differences. It can also serve as a tool for diagnosing a climate of silence in an organization.

\section{KEY WORDS}

silence in an organization; procedural justice; relational contract; quality of relations; emotional attitude

CORRESPONDING AUTHOR - Prof. Krystyna Adamska, Institute of Psychology, University of Gdansk, 4 Bażyńskiego St., 80-952 Gdansk, Poland, e-mail: psyka@ug.edu.pl

Authors' COntributions - A: Study design - B: Data collection · C: Statistical analysis · D: Data interpretation ·

E: Manuscript preparation · F: Literature search · G: Funds collection

to CITE this ARTICLE - Adamska, K., \& Jurek, P. (2017). Adaptation of the Four Forms of Employee Silence Scale

in a Polish sample. Current Issues in Personality Psychology, 5(4), 303-312.

RECEIVED 18.02.2017 · REVIEWED 5.04.2017 • ACCEPTED 13.04.2017 • PUBLISHED 13.06.2017 


\section{BACKGROUND}

Silence in an organization is defined as withholding information, opinions and concerns about matters relating to the organization. Silence is one of the main obstacles to innovation and growth of an organization (Morrison, 2014; Morrison \& Milliken, 2000). Milliken, Morrison and Hewlin (2003) found in qualitative studies that $85 \%$ of managers and professionals did not share critical organizational information. Employee silence has been linked to many important individual and organizational outcomes: decreased innovation (Argyris \& Schön, 1978; Morrison, 2011; Knoll \& van Dick, 2013), failure to react to ethical transgressions (Klammer, Skarlicki, \& Barclay, 2001; Rothwell \& Baldwin, 2007), stress and depression (Cortina \& Magley, 2003), lower creativity and productivity (Hays-Thomas, 2003), and accidents in aviation (Bienefeld \& Grote, 2012). These negative consequences of silence in an organization motivated researchers to study factors responsible for modifying silence. They directed their attention to styles of management, personality of managers, group and organizational climate (Donaghey, Cullinane, Dundon, \& Wilkinson, 2011; Fast, Burris, \& Bartel; 2014, Islam \& Zyphur, 2005; Morrison, 2014; Perlow \& Repenning, 2009; Van Dyne, Ang, \& Botero, 2003) and employee's personality (Tangirala, Kamdar, Venkataramani, \& Parke, 2013).

The motivation for being silent is embedded in the social relations in an organization. Employee silence is a decision how to behave in a particular social context; it is "the withholding of any form of genuine expression about the individual's behavioral, cognitive, and/or affective evaluations of his or her organizational circumstances to persons who are perceived to be capable of effecting change" (Pinder \& Harlos, 2001 , p. 334). Silence is not only conceived as an upward communication-related process. Withholding ideas and information can also be part of the broader organizational context. Sharing knowledge with colleagues or teammates as part of creativity and innovation endeavors is limited when employees experience generalized negative affective states, which is the case in high job demands such as workload or ambiguity (Madrid, Patterson, \& Leiva, 2015). The importance of affective factors was also underlined by Perlow and Williams (2003, who showed that silence generates feelings of humiliation and anger and these limit creativity and undermine productivity.

Though there are researchers who study silence as though it were a unitary construct, not all agree with this claim (Milliken et al., 2003; Pinder \& Harlos, 2001; Van Dyne et al., 2003). The arguments for conceptualizing silence as a multidimensional construct and not the simple oppositions of voice are theoretical and also based on studies. There are small correlations between silence and voice (Madrid et al., 2015). Both are acknowledged as a kind of proactive behavior (Parker \& Collins, 2010). There are different kinds of voice (Maynes \& Podsakoff, 2014) and different motives for silence (Brinsfield, 2013). In the opinion of Knoll and van Dick, studying silence as a unitary concept "is an impediment of the progress in understanding why and when employees withhold their opinion, their knowledge and especially their concerns" (Knoll \& van Dick, 2013, p. 350). There are at least four reasons for which employees restrain themselves from speaking up: 1) the negative view of possibilities of change (acquiescent silence), 2) fear of negative consequences for oneself of speaking up (quiescence silence), 3) the need to maintain harmonious relations with others (prosocial silence), 4) the need to protect and enhance one's interests (opportunistic silence).

\section{FOUR TYPES OF SILENCE}

Acquiescent silence is passive and generalized (Van Dyne et al., 2003). It is in the core of the organization's membership concept. The belief that personal efforts to improve the situation both in productivity and morality are futile because there is nobody to hear the constructive voice involuntarily leads to maintaining the system (Pinder \& Harlos, 2001). The passive acceptance of the status quo means that the alternatives are not recognized and there is no will to change the situation. The belief that speaking up is pointless comes from previous efforts to raise more substantive issues that fell upon deaf ears. This form of silence demands broad assistance to break it.

Quiescent silence is based on the fear that the consequences of speaking up will be personally costly (Morrisson \& Milliken, 2000; Pinder \& Harlos, 2001). This kind of silence is more proactive than acquiescent silence and more consciously driven by considerations of negative outcomes. The idea of fear-based silence is elaborated in the study of psychological safety that is a critical precondition for speaking up in the work context (Edmondson, 1999). The MUM effect is stressed in describing the core of quiescent silence (Van Dyne et al., 2003). This effect emerges when people refrain from delivering bad news to avoid such negative consequences as personal discomfort, which could be evoked by negative responses of the recipients (Lee, 1993). Quiescent silence does not have to be consciously driven. This is the case when the intensity of fear is high and an automatic response is activated in situations such as challenging the authorities (Kish-Gephart, Detert, Treviño, \& Edmondson, 2009).

Prosocial silence is based on altruism and cooperative motives. The beneficiaries are other people or the whole organization. In its essence, prosocial 
silence can be related to the organizational citizenship behavior phenomenon (Smith, Organ, \& Near, 1983; Bateman \& Organ, 1983), which is discretionary behavior, without being mandated by an organization. Other employee's prosociality may be assessed with such statements as: "This employee withholds confidential information, based on cooperation", "This employee protects proprietary information in order to benefit the organization", "This employee withstands pressure from others to tell the organization's secrets" (Van Dyne et al., 2003). Prosocial silence is intentional and proactive. Prosocial silence could be related to prosocial rule breaking, that is conscious actions undertaken to effectively complete a task or to maintain positive relations with clients when the action does not comply with organizational rules (Morrison, 2006; Dahling, Chau, Mayer, \& Gregory, 2012).

The fourth type of silence - opportunistic silence - was proposed by Knoll and van Dick (2013), who define it as deliberately withholding information to gain egoistic profit. The authors consider different manifestations of opportunism including delivering incomplete or distorted information. The aim of this practice is to preserve power and status if it is threatened by prospective changes. Opportunistic silence could also be a tactic to avoid additional workload by misleading or confusing. That is why the authors name it deviant silence, assuming that an employee is aware of the harm done to others.

\section{MEASUREMENT OF ORGANIZATIONAL SILENCE}

Silence has been assessed mainly through qualitative research and case studies (Milliken et al., 2003; Morrison \& Milliken, 2000; Perlow \& Repenning, 2009). To measure quiescent and acquiescent silence Parker, Bindl, Van Dyne, and Wong (2009) proposed a 10 -item scale. In this tool in the acquiescent silence subscale the authors included such items as "My view would make no difference," or "No one would take much notice of my concerns". In the quiescent silence subscale items can be found such as "I would not want to hurt my career," or "I would not want to hurt my position in the team". Acquiescent silence, defensive silence, and prosocial silence could also be measured by a 15 -item scale developed by Van Dyne et al. (2003). Example items include: "I am unwilling to speak up with suggestions for change because I am disengaged," "I do not speak up and suggest ideas for change, based on fear." Briensfield (2013) developed a 31-item scale that consists of six dimensions of motives for silence (ineffectual, relational, defensive, diffident, disengaged, and deviant). The climate of silence was assessed by Vakola and Bouradas (2005), the group voice climate by Morrison et al. (2011) and employees' beliefs about when and why speaking up at work is risky or inappropriate by Detert and Edmondson (2011). Morrison and Milliken (2000) proposed that the climate of silence is a collectively shared belief that speaking up on critical issues is not only futile but also can be dangerous. The climate of silence is formed through organizational structures and policies and managements' implicit beliefs.

Knoll and van Dick (2013) developed a measure for the distinct assessment of the four forms of organizational silence - acquiescent, quiescent, prosocial and opportunistic silence - and demonstrated its usefulness. The authors showed that there is a positive correlation between an organizational climate of silence and three forms of employee silence excluding prosocial silence. They delivered evidence that correlations with the climate of silence were stronger for acquiescent silence compared to quiescent and opportunistic silence. The authors verified the hypothesis of a correlation between organizational identification and acquiescent silence with the conclusion that silence does not have to be associated with negative attitudes toward the organization. They also found negative correlations for all forms of silence with job satisfaction and well-being and positive correlations with strain. The results for employees who engaged in opportunistic silence were a surprise for Knoll and van Dick because contrary to expectations these employees reported the lowest scores in well-being and experienced strain. This convinced the authors of the scale of the necessity to redefine the meaning of opportunistic silence. Finally they established that turnover is positively related to all forms of silence.

\section{THE PRESENT STUDY}

The aim of the study is to examine the validity of the Four Forms of Employee Silence Scale (Knoll \& van Dick, 2013) in a Polish sample ${ }^{1}$ and to establish the criterion-related validity of the scale by correlating the four forms of silence with measures of emotional attitude toward the organization, procedural justice, relational contract and turnover intention. Emotional attitude toward work in an organization, as an important element of employees' attitudes, is strongly connected with satisfaction, engagement, burnout, workaholism and organizational commitment (Barbier, Peters, \& Hansez, 2009). The emotional aspect of the employee's attitude is not only the result of the employee's judgment of employee-employer relations but is also a part of the experience that actively participates in behavior regulation (Yu, 2009). The relational psychological contract is a broad, long-term, socio-emotional set of mutual obligations between employer and employee (Rousseau, 1995). It stresses such values as commitment and loyalty and is consistent with collective interest. When organizations show care and support for employees by providing 
favorable contracts and working conditions then an employee perceives relations in an organization through the lens of relational contract, and develops high trust in the organization and a sense of belonging (Behery, Paton, \& Hussain, 2012). The studies showed that a climate of fairness plays an important role in enhancing motivation to speak up at work (Pinder \& Harlos, 2001), and, specifically, employees are less silent when they perceive a high level of procedural justice (Tangirala \& Ramanujam, 2008).

\section{METHOD}

\section{SCALE TRANSLATION}

The scale was translated into Polish by following the recommendations of Guidelines for Translating and Adapting Tests (International Test Commission, 2005). The emphasis was put on an equivalent linguistic transfer. There were two translation teams including a total of two psychologists, three professional translators from English into Polish and two English native speakers who knew the Polish language (back translation). One member of the research team who is qualified in psychology supervised the whole process. The aim of the team was to uphold the colloquial character of the items in the new version. The two independent teams of translators discussed differences between the back-translations and the original English items, and any necessary corrections were carried out.

\section{PARTICIPANTS AND PROCEDURE}

We collected data from eight samples including a total of 1044 employees of various organizations working for at least six months at a given position. The survey was anonymous and voluntary. Employees were asked to complete questionnaires in paper or electronic form (access to the study was restricted by password).

Sample $1(n=204)$ included 81 men and 123 women; 170 employees held non-managerial positions and 34 managerial; the mean age was $31.8(S D=10.8)$ and average seniority was $10.6(S D=10.1)$. Sample 2 $(n=176)$ consisted of employees of small and medium-sized companies, including 67 men and 119 women; 143 employees held non-managerial positions and 33 managerial; the mean age was $30.2(S D=7.6)$ and average seniority was $7.7(S D=7.2)$. Sample 3 $(n=161)$ consisted of the managers of different companies, participants of MBA studies, including 89 men and 72 women; 37 employees held non-managerial positions (candidates for managers) and 123 managerial; the mean age was $39.8(S D=7.4)$ and average seniority was $16.6(S D=7.5)$. Sample $4(n=100)$ included 30 men and 70 women; 82 employees held non-managerial positions and 18 managerial; the mean age was $34.7(S D=9.3)$ and average seniority was $12.8(S D=9.7)$. Sample $5(n=184)$ included 57 men and 127 women; 122 employees held non-managerial positions and 62 managerial; the mean age was $39.1(S D=10.5)$ and average seniority was $16.5(S D=11.1)$. Sample $6(n=78)$ consisted of employees of several branches of an international company, including 38 men and 40 women; 69 employees held non-managerial positions and 9 managerial; the mean age was $30.5(S D=6.3)$ and average seniority was $7.5(S D=6.9)$. Sample $7(n=72)$ consisted of employees starting their careers, including 8 men and 64 women; the mean age was 26.8 $(S D=2.7)$. Sample $8(n=69)$ included employees of a Polish organization (in order to ensure anonymity, the subjects did not enter demographic data).

\section{MEASURES}

Four Forms of Employee Silence. We used the 12-item measure from the final version of the scale created by Knoll and van Dick (2013). The scale consists of statements to complete the item root "Sometimes I remain silent at work..." with a seven-point scale from 1 (never) to 7 (very often). The results of confirmatory factor analysis of the original and Polish versions of the scale are reported in Table 1 . The tool was used in all eight samples.

Positive and negative emotional attitude toward the organization. We used the 14-item Emotional Attitude towards the Organization Scale (Jurek \& Adamska, in press). The original questionnaire was developed and validated in Poland. The tool consists of seven items referring to negative emotions associated with the workplace (e.g. "What happens in my workplace exhausts me mentally", "I feel bad in my workplace") and seven items referring to positive emotions (e.g. "I owe a lot to my organization", "I feel proud that I work for my organization"). Items are answered on a five-point Likert scale from 1 (completely disagree) to 5 (completely agree). The tool was used in samples 1,2 and 8.

Procedural justice. This is a subscale of the Organizational Justice Scale of Colquitt (2001). It consists of seven items preceded by the remark that "the following items refer to the procedures used in your organization" and asks questions to what extent: Have you been able to express your views and feelings during those procedures? Have you had an influence over the (outcome) arrived at by those procedures? Have you been able to appeal the (outcome) arrived at by those procedures? Have those procedures upheld ethical and moral standards? A seven-point Likert scale from 1 (completely disagree) to 7 (completely agree) was used for answering the questions. The scale was adapted 
to the Polish sample and proved to be reliable (Retowski \& Adamska, 2015). The tool was used in samples 3 and 8.

Turnover intention. The subjects were asked to answer what is the chance that they would react to an unpleasant incident in their workplace in the following way: "considering the possibility of changing jobs" and "looking for job advertisements that would fit you". These two items come from the Polish version of the questionnaire that measures employees' reactions to difficult situations (EVLN model; Hagedoorn, Van Yperen, Van de Vliert, \& Buunk, 1999) in the adaptation by Retowski and Chwiałkowska-Sinica (2004). Items are answered on a five-point Likert scale from 1 (completely disagree) to 5 (completely agree). The tool was used in sample 2.

Relational psychological contract was measured by the subscale of the Swiss Psychological Contract Measure (Raeder, Wittekind, Inauen, \& Grote, 2009). The subscale contains 13 items ranging from 1 (not at all) to 5 (very much) related to different aspects of the relational psychological contract in organizations (e.g. loyalty, decision-making, career development, safety, working atmosphere). Subjects were evaluated on how much their employer offers a working environment where these opportunities are realized. This is in line with the concept of psychological contract, which is implicit, rarely discussed and mainly accessible during the process of change but not when a routine reaction is needed (Schalk \& Roe, 2007). The original version of the scale, in addition to the employer's offer subscale, measures three other subscales: employee's expectations, employee's contribution and employer's expectations. The tool was used in samples 6 and 8 .

The coefficients of reliability for the measurement of all variables are reported in Table 3 .

\section{RESULTS}

\section{CONFIRMATORY FACTOR ANALYSIS}

We conducted a series of confirmatory factor analyses (CFAs) to test whether the four forms of employee silence were empirically distinct concepts in the Polish sample. In the data analysis we used the $\mathrm{R}$ system for statistical computing ( $R$ Development Core Team, 2012) and the R package lavaan (Rosseel, 2012). Multiple model fit indices were reported, including the chi-square statistic $\left(\chi^{2}\right)$, comparative fit index (CFI) and the root mean square error of approximation (RMSEA). To assess the fit of the model to the data, we used the criteria recommended by $\mathrm{Hu}$ and Bentler (1999) and Brown (2015). We accepted CFI values greater than .95 and RMSEA values lower than .08. CFA results confirmed the superiority of the four-factor model (see Table 1). This model provides a good fit $\left[\chi^{2}(n=1044)=143.67 ; d f=48 ;\right.$ CFI = .99; RMSEA $=.044]$ and a significantly better fit than the uni-dimensional model $\left[\chi^{2}(n=1044)=504.29\right.$; $d f=54 ; \mathrm{CFI}=.96 ;$ RMSEA $=.089] ; \Delta \chi^{2}=360.62, \Delta \mathrm{CFI}$ $=.03$. The obtained results support the conclusions presented by Knoll and van Dick (2013).

Finally, Cronbach's $\alpha$ coefficients were used to assess the internal consistency of the four subscales measured by Four Forms of Employee Silence Scale in each sample separately (see Table 2 for details). Cronbach's $\alpha$ between .75 to .85 (for total sample) indicate a good level of reliability.

\section{VALIDITY}

Criterion-related validity was established by correlating four forms of employee silence with constructs theoretically linked to this phenomenon: emotional attitude toward an organization, procedural justice, relational contract and turnover intention. Table 3 presents an overview of the descriptive statistics and bivariate correlations between the four forms of employee silence and the variables included in the study.

A consistent pattern of positive relationship among four forms of silence and negative emotional attitude toward an organization and turnover intention emerged. Individuals with a high score on the negative emotional attitude and turnover intention also reported higher levels of silence, especially acquiescent and quiescent. There also were significant negative correlations between employee silence and positive emotional attitude toward an organization, procedural justice and perceived relational contract. Again, the strongest correlations were reported in the cases of acquiescent and quiescent silence.

\section{CONCLUSION AND DISCUSSION}

The aim of this paper was to examine the reliability and validity of the Polish version of the Four Forms of Employee Silence Scale, which measures four different motives for keeping silence. CFA results confirmed the superiority of the four-factor model and a significantly better fit than the uni-dimensional model or other alternative models with two or three factors. The analyses provide evidence for a good level of internal consistency of the scale. In a sample of 1044 employees the value of Cronbach's $\alpha$ ranges between .75 and .85 . Criterion-related validity was established by demonstrating a positive correlation of silence with negative emotional attitude toward an organization and turnover intention. It is also showed that silence drops with a more positive emotional attitude toward an organization and higher evaluation of procedural justice and relational contract. 
Table 1

Properties of the 12 items of the Four Forms of Employee Silence Scale and its CFA factor loadings

\begin{tabular}{|c|c|c|c|c|c|c|c|c|c|c|}
\hline \multirow{3}{*}{$\begin{array}{l}\text { Item root: I remained silent at work... } \\
\text { (Items of the Polish version of the scale } \\
\text { are in italics in parentheses) }\end{array}$} & \multicolumn{5}{|c|}{ Original version } & \multicolumn{5}{|c|}{ Polish version } \\
\hline & \multirow[t]{2}{*}{$M(S D)$} & \multicolumn{4}{|c|}{ Factor } & \multirow[t]{2}{*}{$M(S D)$} & \multicolumn{4}{|c|}{ Factor } \\
\hline & & AS & PS & OS & QS & & AS & PS & OS & QS \\
\hline $\begin{array}{l}\text { Because I will not find a sympathetic } \\
\text { ear, anyway (ponieważ i tak nikt mnie } \\
\text { nie wystucha) }\end{array}$ & $3.43(2.03)$ & .88 & & & & $2.91(1.78)$ & .80 & & & \\
\hline $\begin{array}{l}\text { Because nothing will change, anyway } \\
\text { (bo to i tak niczego nie zmieni) }\end{array}$ & $3.79(1.94)$ & .86 & & & & $3.40(1.95)$ & .83 & & & \\
\hline $\begin{array}{l}\text { Because my superiors are not open to } \\
\text { proposals, concerns, or the like (po- } \\
\text { nieważ moi przełożeni nie sq otwarci na } \\
\text { propozycje, rozmowy o watpliwościach) }\end{array}$ & $3.68(2.06)$ & .82 & & & & $3.27(1.87)$ & .71 & & & \\
\hline $\begin{array}{l}\text { Because I do not want to embarrass } \\
\text { others (bo nie chcę wprawić innych } \\
\text { w zaktopotanie) }\end{array}$ & $3.92(1.85)$ & & .88 & & & $3.48(1.77)$ & & .80 & & \\
\hline $\begin{array}{l}\text { Because I do not want to hurt the feel- } \\
\text { ings of colleagues or superiors (bo nie } \\
\text { chcé ranić uczuć wspótpracowników lub } \\
\text { przetożonych) }\end{array}$ & $3.71(1.88)$ & & .91 & & & $3.71(1.75)$ & & .80 & & \\
\hline $\begin{array}{l}\text { Because I do not want others to get } \\
\text { into trouble (ponieważ nie chcę, żeby } \\
\text { inni mieli ktopoty) }\end{array}$ & $3.39(1.78)$ & & .82 & & & $3.72(1.81)$ & & .82 & & \\
\hline $\begin{array}{l}\text { Because that would mean having to } \\
\text { do avoidable additional work (aby nie } \\
\text { doprowadzić do dodatkowego obciąże- } \\
\text { nia praca, której można uniknąć) }\end{array}$ & $2.46(1.60)$ & & & .56 & & $2.71(1.67)$ & & & .79 & \\
\hline $\begin{array}{l}\text { Because of concerns that others } \\
\text { could take an advantage of my ideas } \\
\text { (ponieważ obawiam się, że pozostali } \\
\text { mogliby wykorzystać moje pomysty) }\end{array}$ & $1.90(1.30)$ & & & .82 & & $2.69(1.64)$ & & & .71 & \\
\hline $\begin{array}{l}\text { So as not to give away my knowledge } \\
\text { advantage (żeby nie stracić przewagi } \\
\text { wynikającej z mojej wiedzy) }\end{array}$ & $1.94(1.33)$ & & & .78 & & $2.61(1.71)$ & & & .62 & \\
\hline $\begin{array}{l}\text { Because of fear of negative conse- } \\
\text { quences (ponieważ boję się przykrych } \\
\text { konsekwencji) }\end{array}$ & $3.28(1.96)$ & & & & .90 & $3.38(1.86)$ & & & & .79 \\
\hline $\begin{array}{l}\text { To avoid being vulnerable in the face } \\
\text { of colleagues or superiors (ponieważ } \\
\text { nie chcę się narażać wspótpracownikom } \\
\text { lub przetożonym) }\end{array}$ & $3.35(1.93)$ & & & & .80 & $3.47(1.84)$ & & & & .83 \\
\hline $\begin{array}{l}\text { Because I fear disadvantages from } \\
\text { speaking up (ponieważ boję się kon- } \\
\text { sekwencji, wynikajacych z otwartego } \\
\text { wypowiadania swoich opinii) }\end{array}$ & $3.32(1.91)$ & & & & .85 & $3.06(1.77)$ & & & & .80 \\
\hline
\end{tabular}


Table 2

Cronbach's $\alpha$ for subscales of the Four Forms of Employee Silence Scale

\begin{tabular}{lccccc}
\hline Sample $^{\mathrm{a}}$ & $N$ & \multicolumn{5}{c}{ Cronbach's $\alpha$} \\
\cline { 3 - 6 } & & $\begin{array}{c}\text { Acquiescent } \\
\text { Silence }\end{array}$ & $\begin{array}{c}\text { Prosocial } \\
\text { Silence }\end{array}$ & $\begin{array}{c}\text { Opportunistic } \\
\text { Silence }\end{array}$ & $\begin{array}{c}\text { Quiescent } \\
\text { Silence }\end{array}$ \\
\hline 1 & 204 & .84 & .84 & .74 & .88 \\
2 & 176 & .74 & .80 & .64 & .77 \\
3 & 161 & .72 & .81 & .75 & .77 \\
4 & 100 & .87 & .89 & .80 & .78 \\
5 & 184 & .86 & .86 & .72 & .88 \\
6 & 78 & .91 & .76 & .85 & .90 \\
7 & 72 & .82 & .87 & .86 & .84 \\
8 & 69 & .70 & .80 & .66 & .87 \\
Total & 1044 & .82 & .85 & .75 & .84 \\
\hline
\end{tabular}

Note. ${ }^{\mathrm{a}}$ For details see Participants and Procedure.

Table 3

Reliabilities, descriptive statistics, and intercorrelations among the study variables

\begin{tabular}{|c|c|c|c|c|c|c|c|c|c|c|c|c|c|c|}
\hline Variable & Items & $\alpha$ & $N$ & $M$ & $S D$ & 1 & 2 & 3 & 4 & 5 & 6 & 7 & 8 & 9 \\
\hline $\begin{array}{l}1 \text { Acquies- } \\
\text { cent silence }\end{array}$ & 3 & .82 & $1044^{\mathrm{a}}$ & 9.58 & 4.80 & - & & & & & & & & \\
\hline $\begin{array}{l}2 \text { Quiescent } \\
\text { silence }\end{array}$ & 3 & .84 & $1044^{\mathrm{a}}$ & 9.91 & 4.77 & $.68^{* *}$ & - & & & & & & & \\
\hline $\begin{array}{l}3 \text { Prosocial } \\
\text { silence }\end{array}$ & 3 & .85 & $1044^{\mathrm{a}}$ & 10.90 & 4.67 & $.50^{* *}$ & $.64^{* *}$ & - & & & & & & \\
\hline $\begin{array}{l}4 \text { Opportu- } \\
\text { nistic silence }\end{array}$ & 3 & .75 & $1044^{\mathrm{a}}$ & 8.01 & 4.11 & $.51^{* *}$ & $.53^{* *}$ & $.46^{* *}$ & - & & & & & \\
\hline $\begin{array}{l}5 \text { Positive } \\
\text { emotional at- } \\
\text { titude toward } \\
\text { organization }\end{array}$ & 7 & .92 & $452^{\mathrm{b}}$ & 3.38 & .92 & $-.36^{* *}$ & $-.25^{* *}$ & -.04 & $-.12^{*}$ & - & & & & \\
\hline $\begin{array}{l}6 \text { Negative } \\
\text { emotional at- } \\
\text { titude toward } \\
\text { organization }\end{array}$ & 7 & .88 & $452^{\mathrm{b}}$ & 2.23 & .83 & $.45^{* *}$ & $.37^{* *}$ & $.15^{* *}$ & $.20^{* *}$ & $-.60^{* *}$ & - & & & \\
\hline $\begin{array}{l}7 \text { Procedural } \\
\text { justice }\end{array}$ & 7 & .90 & $235^{c}$ & 23.73 & 6.52 & $-.52^{* *}$ & $-.41^{* *}$ & $-.22^{* *}$ & $-.23^{* *}$ & $.63^{* *}$ & $-.60^{* *}$ & - & & \\
\hline $\begin{array}{l}8 \text { Turnover } \\
\text { intention }\end{array}$ & 2 & .82 & $179^{d}$ & 5.70 & 2.32 & $.27^{* *}$ & $.27^{* *}$ & $.18^{*}$ & $.22^{* *}$ & $-.68^{* *}$ & $.40^{* *}$ & n.d. & - & \\
\hline $\begin{array}{l}9 \text { Relational } \\
\text { contract }\end{array}$ & 13 & .94 & $146^{\mathrm{e}}$ & 49.18 & 10.98 & $-.55^{* *}$ & $-.42^{* *}$ & $-.29^{* *}$ & ${ }^{*}-.32^{* *}$ & $.83^{* *}$ & $-.63^{* *}$ & $.77^{* *}$ & n.d. & - \\
\hline
\end{tabular}

Note. ${ }^{\mathrm{a}}$ All eight samples; ${ }^{\mathrm{b}}$ samples 1,2 and 8 ; ${ }^{\mathrm{c}}$ samples 3 and 8 ; ${ }^{\mathrm{d}}$ sample 2 ; ${ }^{\mathrm{e}}$ samples 6 and $8,{ }^{* *} p<.010,{ }^{*} p<.050$, n.d. - no data.

The rationale for adapting the scale that measures four forms of employee silence to the Polish context is that it gives more possibilities to test hypotheses about links between individuals' behaviors, leaders' behaviors and organizational climate. Such an instrument would enable us to understand what is hidden in social relations, offering an insight into the communication processes. A reliable scale would help to verify the contradictory claims related to the voice-silence phenomenon. The answer to the ques- 
tion whether silence and voice are a unidimensional construct or rather two distinct constructs could be useful in the research on change, its limit and management tactics to conduct change. The validation of the scale in the Polish sample encourages quantitative studies of silence in the domain of its antecedents and consequences. It may help to develop the theory of silence in an organization by answering scientific questions about the role of management style, personality of the employee and supervisor, the role of attitudes toward an organization and other individual factors influencing the intensity of silence.

The theoretical bases of the silence phenomenon indicate that silence as an individual decision to withdraw from voicing ideas, suggestions, criticisms and opinions may be an effect of a belief shared with other employees that voicing is futile or even dangerous (Detert \& Edmondson, 2011; Fivush, 2010; Pinder \& Harlos, 2001). Sharing reality with others drives social actions. The tendency to protect common understanding by alignment with similar others and contrast beliefs and behaviors with socially distant others is strong enough to sacrifice objectively verifiable knowledge (Hardin \& Higgins, 1996). The present study shows that two forms of silence, that is acquiescent and quiescent silence, are related to positive and negative emotional attitudes toward the organization, procedural justice, turnover intention and relational contract more strongly than to prosocial and opportunistic silence. This is partly in line with Knoll's and van Dick's (2013) evidence that correlations with climate of silence were strongest for acquiescent silence and their observation that organizational identification correlates only with acquiescent silence. These results and theoretical considerations could give rise to studies of different forms of silence climate. Sharing beliefs in a particular organizational setting about the futility or danger of speaking up at work would form a different climate of silence (with different consequences) than when silence is motivated prosocially or opportunistically.

The limitation of the study can be seen in the lack of predictors of silence in an organization at the institutional level. To use the scale for inter-organizational comparisons would require inclusion of such information about the organization as its size, type of ownership, systems and practices of human resources management. These characteristics of an organization are crucial for differentiating organizational behaviors and, in consequence, for verifying the hypothesis that organizational climate can be discerned along different combinations of silences. It may be expected that if organizational practices are embedded in diversity and individualistic values then prosocial and opportunistic silence prevail. In contrast, acquiescent and quiescent silence may be a product of more bureaucratic types of organizations, and based on such values as stability and predictability. So the next step should include recognizing not only individual predictors but also organizational ones.

\section{ENDNOTE}

1 Adaptation was done with the permission of the authors.

\section{References}

Argyris, C., \& Schön, D. (1978). Organizational learning: A theory of action perspective, Reading. Mass: Addison Wesley.

Barbier, M., Peters, S., \& Hansez, I. (2009). Measuring Positive and Negative Occupational States (PNOSI): Structural Confirmation of a New Belgian Tool. Psychologica Belgica, 49, 227-247.

Bateman, T. S., \& Organ, D. W. (1983). Job satisfaction and the good soldier: The relationship between affect and employee "citizenship". Academy of Management Journal, 26, 587-595.

Behery, M., Paton, R., \& Hussain, R. (2012). Psychological contract and organizational commitment: The mediating effect of transformational leadership. Competitiveness Review, 22, 299-319.

Bienefeld, N., \& Grote, G. (2012). Silence that may kill: When aircrew members don't speak up and why. Aviation Psychology and Applied Human Factors, 2, 1-10.

Brown, T. A. (2015). Confirmatory Factor Analysis for Applied Research ( $2^{\text {nd }}$ ed.). New York, NY: The Guilford Press.

Brinsfield, C. T. (2013). Employee silence motives: Investigation of dimensionality and development of measures. Journal of Organizational Behavior, 34, 671-697.

Cortina, L. M., \& Magley, V. J. (2003). Raising voice, risking retaliation: Events following interpersonal mistreatment in the workplace. Journal of Occupational Health Psychology, 8, 247-265.

Colquitt, J. A. (2001). On the dimensionality of organizational justice: a construct validation of a measure. Journal of Applied Psychology, 86, 386-400.

Dahling, J. J., Chau, S. L., Mayer, D. M., \& Gregory, J. B. (2012). Breaking rules for the right reasons? An investigation of pro-social rule breaking. Journal of Organizational Behavior, 33, 21-42.

Detert, J. R., \& Edmondson, A. C. (2011). Implicit voice theories: Taken-for-rules of self-censorship at work. Academy of Management Journal, 54, 461-488.

Donaghey, J., Cullinane, N., Dundon, T., \& Wilkinson, A. (2011). Re-conceptualising employee silence: Problems and prognosis. Work, Employment and Society, 25, 51-67. 
Edmondson, A. (1999). Psychological safety and learning behavior in work teams. Administrative Science Quarterly, 44, 350-383.

Fast, N. J., Burris, E. R., \& Bartel, C. A. (2014). Managing to stay in the dark: Managerial self-efficacy, ego defensiveness, and the aversion to employee voice. Academy of Management Journal, 57, 1013-1034.

Fivush, R. (2010). Speaking silence: The social construction of silence in autobiographical and cultural narratives. Memory, 18, 88-98.

Hagedoorn, M., van Yperen, N., van de Vliert, E., \& Buunk, B. (1999). Employees' reactions to problematic events: A circumplex structure of five categories of responses, and the role of job satisfaction. Journal of Organizational Behavior, 20, 309-321.

Hardin, C. D., \& Higgins, E. T. (1996). Shared reality: How social verification makes the subjective objective. In R. M. Sorrentino \& E. T. Higgins (eds.), Handbook of motivation and cognition (vol. 3: The interpersonal context, pp. 28-84). New York, NY: The Guilford Press.

Hays-Thomas, R. (2003). The Last page: Learning by breaking the silence. The Psychologist-Manager Journal, 6, 120-122.

Hu, L., \& Bentler, P. M. (1999). Cutoff criteria for fit indexes in covariance structure analysis: Conventional criteria versus new alternatives. Structural Equations Modeling, 6, 1-55.

International Test Commission (2005). Guidelines for Translating and Adaptating Tests. Retrieved from http: //www.intestcom.org

Islam, G., \& Zyphur, M. J. (2005). Power, voice and hierarchy: Exploring the antecedents of speaking up in groups. Group Dynamics: Theory, Research and Practice, 9, 93-103.

Jurek, P., \& Adamska, K. (in press). Skala Emocjonalnego Nastawienia wobec Organizacji (SENO) - konstrukcja i właściwości psychometryczne narzędzia [Positive and Negative Organizational Attitudes Scale: designing and psychometric properties]. Psychologia Spoteczna.

Kish-Gephart, J. J., Detert, J. R., Treviño, L. K., \& Edmondson, A. C. (2009). Silenced by fear: The nature, sources, and consequences of fear at work. Research in Organizational Behavior, 29, 163-193.

Klammer, J., Skarlicki, D. P., \& Barclay, L. (2001). Speaking up in the Canadian military: The role of voice, being heard, and generation in predicting civic virtue. Canadian Journal of Behavioral Science, 34, 122-130.

Knoll, M., \& von Dick, R. (2013). Do I hear the whistle...? A first attempt to measure four forms of employee silence and their correlates. Journal of Business Ethics, 113, 349-362.

Lee, F. (1993). Being polite and keeping MUM: how bad news is communicated in organizational hi- erarchies. Journal of Applied Social Psychology, 23, 1124-1149.

Madrid, H. P., Patterson, M. G., \& Leiva, P. I. (2015). Negative core affect and employee silence: How differences in activation, cognitive rumination, and problem-solving demands matter. Journal of Applied Psychology, 100, 1887-1898.

Maynes, T. D., \& Podsakoff, P. M. (2014). Speaking more broadly: An examination of the nature, antecedents, and consequences of an expanded set of employee voice behaviors. Journal of Applied Psychology, 99, 87-112.

Milliken, F. J., Morrison, E. W., \& Hewlin, P. F. (2003). Choosing to stay silent at work: What employees don't speak about and why. Journal of Management Inquiry, 40, 1453-1476.

Morrison, W. E. (2006). Doing the job well: An investigation of pro-social rule breaking. Journal of Management, 32, 5-28.

Morrison, E. W. (2011). Employees voice behavior. Integration and directions for future research. The Academy of Management Annals, 5, 373-412.

Morrison, E. W. (2014). Employee voice and silence. The Annual Review of Organizational Psychology and Organizational Behavior, 1, 173-197.

Morrison, E. W., \& Milliken, F. J. (2000). Organizational silence: A barrier to change and development in a pluralistic world. Academy of Management Review, 25, 706-725.

Parker, S. K., Bindl, U. K., van Dyne, L., \& Wong, S. F. (2009). Measuring motives for silence. Paper presented at the annual meeting of the Academy of Management, Chicago, IL.

Parker, S. K., \& Collins, C. G. (2010). Taking stock: Integrating and differentiating multiple proactive behaviors. Journal of Management, 36, 633-662.

Perlow, L. A., \& Repenning, N. P. (2009). The dynamics of silencing conflict. Research in Organizational Behavior, 29, 195-223.

Pinder, C. C., \& Harlos, K. P. (2001). Employee silence: Quiescence and acquiescence as response to perceived injustice. In G. R. Ferris (ed.), Research in personnel and human resources management (vol. 20, pp. 331-369). Greenwich, CT: JAI Press.

$\mathrm{R}$ Development Core Team (2012). R: A Language and Environment for Statistical Computing. R Foundation for Statistical Computing, Vienna, Austria. Retrieved from http: //www.R-project.org/

Retowski, S., \& Chwiałkowska-Sinica, A. (2004). Achievement Motivation and Locus of Control as Determinants of Exit, Voice, Loyalty, and Neglect Behaviors within Organization. European Group for Organizational Studies (EGOS).

Rosseel, Y. (2012). lavaan: An R Package for Structural Equation Modeling. Journal of Statistical Software, 48, 2, 1-36.

Raeder, S., Wittekind, A., Inauen, A., \& Grote, G. (2009). Testing a psychological contract measure 
in a Swiss employment context. Swiss Journal of Psychology, 68, 177-178.

Retowski, S., \& Adamska, K. (2015). Adaptation of the Organizational Justice Scale of Jason Colquitt in a Polish sample. Unpublished manuscript.

Rothwell, G. R., \& Baldwin, J. N. (2007). Ethical climate theory, whistle-blowing, and the code of silence in police agencies in the state of Georgia. Journal of Business Ethics, 70, 341-361.

Rousseau, D. (1995). Psychological contract in organizations: Understanding written and unwritten agreements. Thousand Oaks, CA: Sage.

Smith, C. A., Organ, D. W., \& Near, J. P. (1983). Organizational citizenship behavior: Its nature and antecedents. Journal of Applied Psychology, 68, 655-663.

Tangirala, S., Kamdar, D., Venkataramani, V., \& Parke, M. R. (2013). Doing right versus getting ahead: the effects of duty and achievement orientations on employees' voice. Journal of Applied Psychology, 98, 1040-1050.

Tangirala, S., \& Ramanujam, R. (2008). Employees silence on critical work issues: the cross level effect of procedural justice climate. Personnel Psychology, 61, 37-68.

Vakola, M., \& Bourades, D. (2005). Antecedents and consequences of organizational silence: An empirical investigation. Employee Relations, 27, 441-458.

Van Dyne, L., Ang, S., \& Botero, I. C. (2003). Conceptualizing employee silence and employee voice as multidimensional constructs. Journal of Management Studies, 40, 1359-1392.

Yu, K. Y. T. (2009). Affective influences in Person-Environment Fit Theory: Exploring the role of Affect as both cause and outcome of P-E fit. Journal of Applied Psychology, 94, 1210-1226. 